\title{
MOVEMENT ASSESSMENT BATTERY FOR CHILDREN - SECOND EDITION: CROSS-CULTURAL COMPARISON BETWEEN 11-15 YEAR OLD CHILDREN FROM THE CZECH REPUBLIC AND THE UNITED KINGDOM
}

\author{
Rudolf Psotta, Jan Hendl* \\ Faculty of Physical Culture, Palacký University, Olomouc, Czech Republic \\ ${ }^{*}$ Faculty of Physical Education and Sport, Charles University, Prague, Czech Republic
}

Submitted in July, 2012

BACKGROUND: With the exception of specific clinical methods, no widely used diagnostic tool for motor development assessment of children exists in the Czech Republic. The Movement Assessment Battery for Children - second edition (MABC-2) seems to be one the most developed instruments for children's motor coordination assessment. However, to use it in the Czech population of children in educational and psychological practice including physical education, the cross-validity of the test battery needs to be examined.

OBJECTIVE: The aim of the study was to make a comparative analysis of performance in motor tasks of the MABC-2 measured in a Czech sample of 11-15 year old children and the United Kingdom (UK) normative sample from which the norms of the MABC-2 were established.

METHODS: The Czech sample of 11-15 year old children (total $n=589 ; 310$ boys, 279 girls) formed from a random selection of schools from all the geographical regions of the Czech Republic and all size categories of municipalities, was tested by the MABC-2. The results were compared to the performance of the UK normative sample of the same age $(n=344)$ reported in the MABC-2 Examiner's Manual by Henderson et al. (2007). For this comparative analysis, the effects size coefficient (d) and the z-test were used.

RESULTS: From three manual dexterity tests of the MABC-2, mean performance of the Czech sample in the Drawing trail test was shown to be significantly higher than the mean performance of the UK sample in all the age groups of both genders $(d=0.68-1.32 ; p<0.01)$. On the other hand, the Czech sample demonstrated no significant differences of performance in the gross motor coordination tests as compared to the performance of the UK sample. Regarding balance assessment, performance in the Two-board balance test (static balance) was found to be significantly higher in almost all the age groups of Czech girls $(d=0.52-0.70, p<0.01)$, while Czech boys showed a significantly higher performance only in the Zig-zag hopping test (dynamic balance) at the ages of 14 and 15 years, as compared to the UK sample. In $1.9 \%$ of boys and $0.7 \%$ of girls in the Czech sample significant motor difficulties were identified (total test score $\leq 5^{\text {th }}$ percentile).

CONCLUSIONS: The study revealed that the MABC-2 is valid only for assessment of gross motor coordination in Czech children, but not for assessment of manual dexterity and balance. Before the use of this test battery for Czech children for both practical and research purposes, an adjustment of the norms is needed for the Drawing trail test, Two-board balance test and Zig-zag hopping test.

Keywords: Motor coordination, test, manual dexterity, aiming, catching, balance, child.

\section{INTRODUCTION}

Motor coordination assessment in children is carried out in school education, physical education and sports, educational and psychological advisory, physiotherapy and child neurology. With the exception of specific neurological clinical methods, in the Czech Republic no broadly used diagnostic tool for motor coordination assessment of children exists. In spite of the fact that assessment of motor functions in children is an important part of monitoring of total development of their organism. Motor assessment is needed to identify normal or impaired motor coordination, individual educational needs of a child, and predispositions for participation in sports, or to evaluate intervention programmes focused on improvement of motor skills. Also longitudinal research on children's motor development is associated with the use of proper assessment instruments (Henderson, Sugden, \& Barnett, 2007).

The Movement Assessment Battery for Children (MABC) (Henderson \& Sugden, 1992) has been recognized as one the most frequently used children's motor assessment method (Larkin \& Rose, 2005; Yoon, Scott, Hill, Levitt, \& Lambert, 2006). With this method functioning of the motor system in a child is assessed indirectly from performance achieved in the motor test 
tasks. Thus, these motor tasks indicate motor abilities on the behavioral level.

On the basis of considerable structural and content changes to the MABC, a new improved version of this battery was issued, the Movement Assessment Battery for Children-2 (MABC-2) (Henderson et al., 2007). This battery enables the assessment of children's motor coordination from performance achieved in the eight motor tests focused on three motor components - fine motor coordination (manual dexterity), gross motor coordination (aiming and catching) and balance. This test battery involves three age-modified sets of the motor tests for particular age bands - 3-6, 7-10 and 11-16 year old children.

The MABC-2 is the result of the long-term development of an instrument for children's motor coordination assesment and identification of developmental coordination disorder (DCD). However, Brown and Lalor (2009) suggested the lack of evidence on validity of this battery. These authors noted that validity data reported for the MABC were generalized to the MABC-2 with insufficient investigation on validity of this new battery. The reliability of the MABC-2 was reported as excellent with the intra-class correlation ICC $=0.97$ and the internal consitency of the test battery Cronbach $\alpha=0.90$ in 6-12 year old children (Wuang et al., 2012).

To use the MABC-2 in the population of Czech children by professionals in educational, psychological and clinical practice and also in research, the cross-cultural validity of the battery should be examined. The motor skill tasks contained in the MABC-2 were selected by the authors so that they were equally relevant to all cultural backgrounds and both genders (Henderson et al., 2007). However, these authors admitted at the same time that it is not possible to devise a test that is completely unaffected by cultural specificity.

To the knowledge of the authors, no study on crosscultural validity of the MABC-2 has been published to date. The previous studies with the MABC based on the cross-cultural comparison of the results of testing of children in Greece (Ellinoudis, Kourtessis, \& Kiparissis, 2008), Spain (Ruiz, Graupera, Gutiérrez, \& Miyahara, 2003), Sweden (Rősblad \& Gard, 1998) and Netherlands (Smith-Engelsman, 1998) with the original norms concluded that the MABC can be a useful tool for assessment of child motor development in these countries. However, some cross-cultural differences of performance in the tests were reported and relevant adjustment of the norms recommended.

The comparison of results of testing in a given cohort with the norms derived from original standardization sample is the basic step for examination of the cross-cultural validity of a diagnostic instrument. Therefore, to use the MABC-2 commonly in the population in Czech children, the aim of the study was to examine the differences in motor test performance in a Czech representative sample and the United Kingdom standardization sample of 11-15 year old children from whom the norms of the MABC-2 were established.

\section{METHODS}

\section{Basic design}

The cross-cultural comparison consisted of an analysis of difference in performance in the test tasks of the MABC-2 assessed in the Czech representative sample of 11-15 year old children $(n=589)$ and the United Kingdom (UK) normative standardisation sample of the same age $(n=344)$. For this analysis, the data on performance in the MABC-2 achieved in the UK standardisation sample of the 11-15 year old children $(n=344)$ and reported in the MABC-2 Examiner's Manual (Henderson et al., 2007) were used.

\section{Subjects}

The Czech sample of 11-15 year old children ( $n=589$ ) selected for the study was formed on the basis of a random selection of 17 primary schools from all the geographical regions of the Czech Republic. This sample included 310 boys and 279 girls in the five age groups $-11,12,13,14$ and 15 years old subjects, $n=78$, $95,70,51$ and 16 of boys, and $n=77,71,73,38$ and 20 of girls. From the total sample 114 boys and 108 girls lived in large-sized municipalities (> 90000 inhabitants), 110 boys and 94 girls in medium-sized municipalities ( 5 000-90 000 inhabitants), and 86 boys and 77 girls in small-sized municipalities ( $<5000$ inhabitants). The categories of municipalities were stated according to the methodology of the Czech Statistical Office.

All the schools selected provided education according to the Framework Educational Programme for Elementary Education established by the Czech Ministry of Education. Children with physical and other neurological disabilities were not tested.

\section{Procedures}

The MABC-2 for the age band of 11-16 year old children contains the following tests:

1. Turning pegs (MD 1), triangle with nuts and bolts (MD 2) and drawing trail (MD 3 ) for assessment of manual dexterity;

2. Catching with one hand (AC 1) and throwing at wall target (AC 2); for assessment of gross motor coordination

3. Two-board balance (Bal 1), walking toe-to-heel backwards (Bal 2) and Zig-zag hopping (Bal 3) for assessment of balance. 
Before examination of the MABC-2 in the Czech sample, a pilot verification of the tests in 11-15 year old children $(n=20)$ was completed. On the basis of this verification, the formulation of verbal instructions to children was specified.

Twelve trained testers with a university master's or Ph.D. degree in physical education, kinanthropology or adapted physical education performed the testing. Before testing, all the testers had been trained in the use of the MABC-2 by the first author. Testers' competence in administration of the tests and recording data was checked.

The children of the Czech sample were assessed with the MABC-2 in school settings during the morning. The children of each class performed the individual tests by circulating from one station to another in random order.

This research project had been approved by the institutional review board of the university before submitting it to the Czech Science Foundation for grant support. Approval of the research by the Scientific Panel for Psychology and Education of the Czech Science Foundation followed. The study was conducted in accordance with the Declaration of Helsinki. The testing of children was carried out after receiving informed written consent from school principals, the parents of the children and the participants.

\section{Scoring of the MABC-2}

Scoring of performance in the motor tests was completed according to the MABC-2 Examiner's Manual (Henderson et al., 2007). A raw score achieved in each test was converted to age related item standard score. To assess each of the three motor components - manual dexterity, gross motor coordination and balance, the sum of standard scores achieved in the relevant tests was converted to the component standard score. The total test score (TTS) as an indicator of the all level of motor coordination was calculated as a sum of standard scores of all eight tests followed by conversion to the TTS standard score and its percentile equivalent. All conversions of scores to the standard scores were based on the UK norms (Henderson et al., 2007).

\section{Data analysis}

The practical and statistical significance of differences in performance in each motor test, each motor component and TTS achieved in each age group of both genders of the Czech sample was tested. To assess the practical significance, Cohen's effect size coefficient $d$ was used. The values $d<.50, d=.50-.80$ and $d>.80$ was interpreted as a small, medium and large effect, respectively (Cohen, 1977). If the finding $d \geq .50$ occured, a test of the statistical significance of the difference between the Czech sample means and normative means of UK population using the two-tailed z-test $(p=.05)$ followed. The difference was finally interpreted as sig- nificant if the practical difference $d \geq .50$ was confirmed to be statistically significant. The criterion of the $d \geq .50$ for the following z-test analysis was accepted because of the findings of higher percentage of the subjects who achieved their test performance at the level of $\leq \mathrm{M} \pm 0.5$ SD. This percentage of the children was found in the range of $14-86 \%$ in the particular tests and component scores.

The analyses were performed using NCSS Statistical Software version 2007 (Kaysville, Utah, USA).

\section{RESULTS}

\section{Manual dexterity}

The mean performance of the Czech sample in the Drawing trail test (MD 3) was shown to be significantly higher than the mean performance of the UK sample in all the age groups of both genders as indicated by the effect size coefficients and z-test scores (TABLE 1). Regarding the other manual dexterity tests, a significantly lower performance in the MD 1 test in the 15 year old Czech boys, and in the MD 2 test in 14 year old boys and 15 year old girls was found compared to the UK mean performance.

In spite of the significant difference in performance in the MD 3 test in all age and gender groups of the Czech sample, no significant difference in the mean component scores for manual dexterity between the Czech and the UK sample was found, with the exception of the Czech 11 year old girls (Fig. 1).

\section{Gross motor coordination}

The Czech sample demonstrated no significant differences in performance in both the aiming and catching tests (AC 1 and $A C 2$ ) in comparison to the UK mean performance (TABLE 2). As a consequence, no significant difference in the component standard score for gross motor coordination was found as compared to the UK mean, with the exception of the significanly higher component score in the 11 and 15 year old Czech boys (Fig. 2).

\section{Balance}

As compared to the UK mean, performance in the Two-board balance (Bal 1) test was found to be significantly higher in the four age groups of the Czech girls (TABLE 3). In addition, the Czech girls also achieved a significantly higher performance in the Zig-zag hopping (Bal 3) test at the age of 13 and 15 years, and in the Walking toe-to-heel backwards ( $\mathrm{Bal}$ 2) test at the age of 15 years, in comparison to the UK means (TABLE 3). These differences in balance test performance were accompanied by a significantly higher component score for balance in all age groups of Czech girls, with the exception of 14 year old subjects (Fig. 3). 
TABLE 1

Performance in the manual dexterity tests of the MABC-2 in the Czech children $(n=589)$; the significance of differences as compared to the mean performance of the United Kingdom standardisation sample $(n=344)$

\begin{tabular}{|c|c|c|c|c|c|c|}
\hline \multirow{2}{*}{ TEST } & Standard & \multirow{2}{*}{ d } & z-value & \multirow{2}{*}{$\begin{array}{c}\text { Standard } \\
\text { score }(\mathrm{M} \pm \mathrm{SD}) \\
\end{array}$} & \multirow{2}{*}{ d } & \multirow{2}{*}{$\begin{array}{l}\text { z-value } \\
\text { (z-test) } \\
\end{array}$} \\
\hline & score $(\mathrm{M} \pm \mathrm{SD})$ & & (z-test) & & & \\
\hline & 11 year old boys $(n=78)$ & & & 11 year old girls $(n=77)$ & & \\
\hline MD 1 & $9.9 \pm 2.0$ & 0.04 & & $10.4 \pm 2.3$ & 0.15 & \\
\hline MD 2 & $9.7 \pm 2.7$ & 0.11 & & $8.8 \pm 2.7$ & 0.43 & \\
\hline \multirow[t]{2}{*}{ MD 3} & $12.2 \pm 1.7$ & $1.00^{\mathrm{a}}$ & $11.611 * *$ & $12.5 \pm 1.3$ & $1.32^{\mathrm{a}}$ & $17.600 * *$ \\
\hline & 12 year old boys $(n=95)$ & & & 12 year old girls $(n=71)$ & & \\
\hline MD 1 & $9.2 \pm 2.1$ & 0.33 & & $9.4 \pm 2.2$ & 0.24 & \\
\hline MD 2 & $9.2 \pm 2.6$ & 0.29 & & $9.5 \pm 2.5$ & 0.19 & \\
\hline \multirow[t]{2}{*}{ MD 3} & $12.0 \pm 1.9$ & $0.87^{\mathrm{a}}$ & $10.151 * *$ & $12.4 \pm 1.5$ & $1.20^{\mathrm{a}}$ & $13.233 * *$ \\
\hline & 13 year old boys $(n=70)$ & & & 13 year old girls $(n=73)$ & & \\
\hline MD 1 & $9.7 \pm 2.1$ & 0.13 & & $9.8 \pm 2.2$ & 0.08 & \\
\hline MD 2 & $9.5 \pm 2.7$ & 0.18 & & $8.9 \pm 2.3$ & 0.42 & \\
\hline \multirow[t]{2}{*}{ MD 3} & $12.1 \pm 2.0$ & $0.88^{\mathrm{a}}$ & $8.925 * *$ & $12.6 \pm 1.4$ & $1.30^{\mathrm{a}}$ & $16.273^{* *}$ \\
\hline & 14 year old boys $(n=51)$ & & & 14 year old girls $(n=38)$ & & \\
\hline MD 1 & $8.9 \pm 2.5$ & 0.41 & & $9.7 \pm 1.7$ & 0.13 & \\
\hline MD 2 & $8.8 \pm 1.8$ & $0.55^{\mathrm{b}}$ & $4.756^{* *}$ & $8.9 \pm 2.4$ & 0.41 & \\
\hline MD 3 & $11.5 \pm 1.8$ & $0.68^{\mathrm{b}}$ & $5.781 * *$ & $11.8 \pm 0.9$ & $0.90^{\mathrm{a}}$ & $12.014 * *$ \\
\hline & 15 year old boys $(n=16)$ & & & 15 year old girls $(n=20)$ & & \\
\hline MD 1 & $8.4 \pm 1.8$ & $0.67^{\mathrm{b}}$ & $3.496^{*}$ & $9.7 \pm 2.4$ & 0.11 & \\
\hline MD 2 & $8.4 \pm 2.5$ & $0.57^{\mathrm{b}}$ & 2.498 & $8.2 \pm 2.3$ & $0.64^{\mathrm{b}}$ & $3.561 *$ \\
\hline MD 3 & $11.7 \pm 1.3$ & $0.77^{\mathrm{b}}$ & $5.400 * *$ & $11.8 \pm 1.1$ & $0.78^{\mathrm{b}}$ & $7.000 * *$ \\
\hline
\end{tabular}

Legend: M - mean, SD - standard deviation, $\mathrm{d}$ - Cohen's effect size coefficient, ${ }^{\mathrm{a}}-\mathrm{a}$ large effect size, ${ }^{\mathrm{b}}-\mathrm{a}$ medium effect size, ${ }^{*}-\mathrm{p}<.05$, ** $-\mathrm{p}<.001$, MD 1 - Turning pegs test, MD 2 - Triangle with nuts and bolts test, MD 3 - Drawing trail test

Fig. 1

The component standard score for manual dexterity $(M \pm S D)$ in the Czech children $(n=589)$; the significance of differences as compared to the mean performance of the United Kingdom standardisation sample $(n=344)$

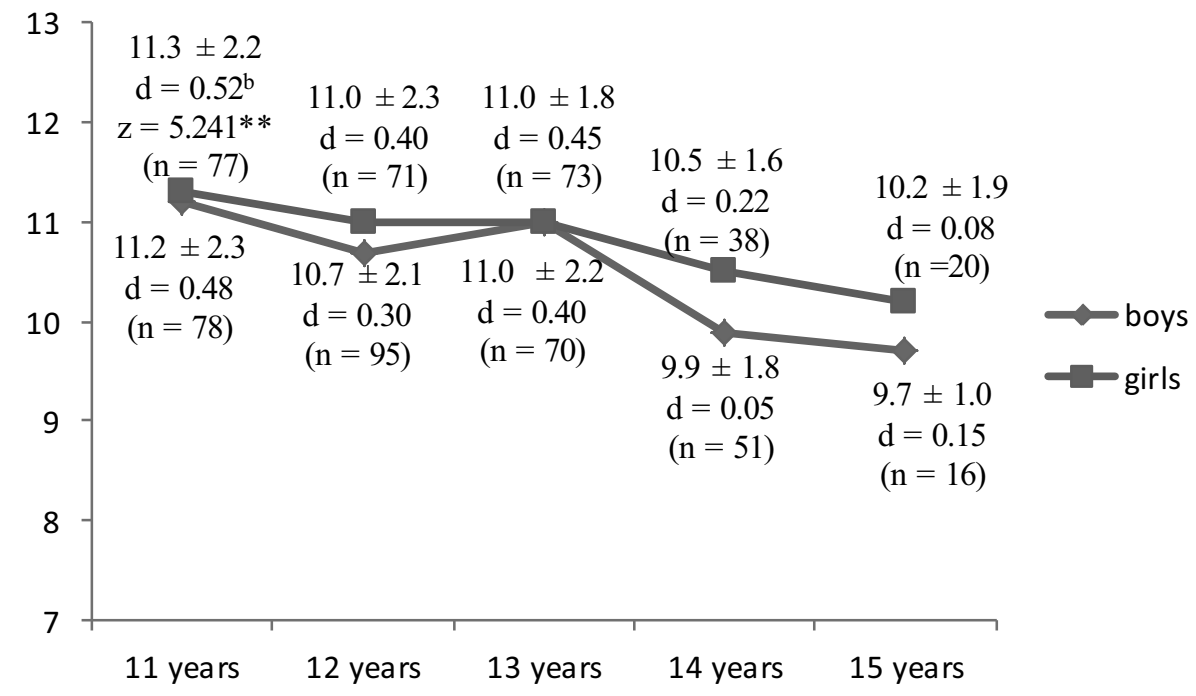

Legend: $\mathrm{d}$ - Cohen's effect size coefficient, ${ }^{\mathrm{b}}-\mathrm{a}$ medium effect size, $\mathrm{z}-\mathrm{z}$-value in the $\mathrm{z}$-test, ${ }^{* *}-\mathrm{p}<.001$ 
TABLE 2

Performance in the gross motor coordination (aiming/catching) tests of the MABC-2 in the Czech children ( $\mathrm{n}=589)$; the significance of differences as compared to the mean performance of the United Kingdom standardisation sample $(\mathrm{n}=344)$

\begin{tabular}{|c|c|c|c|c|c|}
\hline \multirow{2}{*}{ TEST } & Standard & \multirow{2}{*}{ d } & \multirow{2}{*}{$\begin{array}{l}\text { z-value } \\
\text { (z-test) }\end{array}$} & \multirow{2}{*}{$\begin{array}{c}\text { Standard } \\
\text { score }(M \pm \text { SD })\end{array}$} & \multirow{2}{*}{ d } \\
\hline & score $(\mathrm{M} \pm \mathrm{SD})$ & & & & \\
\hline & 11 year old boys $(n=78)$ & & & 11 year old girls $(n=77)$ & \\
\hline $\mathrm{AC} 1$ & $11.2 \pm 2.6$ & 0.41 & & $9.9 \pm 2.6$ & 0.03 \\
\hline \multirow[t]{2}{*}{$\mathrm{AC} 2$} & $10.7 \pm 3.4$ & 0.21 & & $10.3 \pm 3.3$ & 0.09 \\
\hline & 12 year old boys $(n=95)$ & & & 12 year old girls $(n=71)$ & \\
\hline AC 1 & $10.8 \pm 2.8$ & 0.28 & & $9.7 \pm 2.9$ & 0.10 \\
\hline \multirow[t]{2}{*}{ AC 2} & $10.4 \pm 3.0$ & 0.13 & & $9.9 \pm 3.0$ & 0.03 \\
\hline & 13 year old boys $(n=70)$ & & & 13 year old girls $(n=73)$ & \\
\hline AC 1 & $11.3 \pm 2.6$ & 0.48 & & $9.8 \pm 2.6$ & 0.07 \\
\hline \multirow[t]{2}{*}{ AC 2} & $9.2 \pm 2.7$ & 0.29 & & $9.7 \pm 2.5$ & 0.11 \\
\hline & 14 year old boys $(n=51)$ & & & 14 year old girls $(n=38)$ & \\
\hline AC 1 & $9.8 \pm 4.1$ & 0.05 & & $9.8 \pm 3.1$ & 0.07 \\
\hline \multirow[t]{2}{*}{ AC 2} & $10.8 \pm 2.5$ & 0.30 & & $9.2 \pm 2.6$ & 0.29 \\
\hline & 15 year old boys $(n=16)$ & & & 15 year old girls $(n=20)$ & \\
\hline AC 1 & $11.6 \pm 2.3$ & $0.60^{\mathrm{b}}$ & & $9.3 \pm 3.0$ & 0.23 \\
\hline AC 2 & $11.1 \pm 2.8$ & 0.38 & & $10.2 \pm 3.4$ & 0.26 \\
\hline
\end{tabular}

Legend: M - mean, SD - standard deviation, $\mathrm{d}$ - Cohen's effect size coefficient, ${ }^{\mathrm{b}}$ - a medium effect size, ${ }^{*}-\mathrm{p}<.05$, AC 1 - Catching with one hand test, AC 2 - Throwing at wall target test

Fig. 2

The component standard score for gross motor coordination (aiming/catching) ( $\mathrm{M} \pm \mathrm{SD}$ ) in the Czech children $(\mathrm{n}=589)$; the significance of differences as compared to the mean performance of the United Kingdom standardisation sample $(\mathrm{n}=344)$

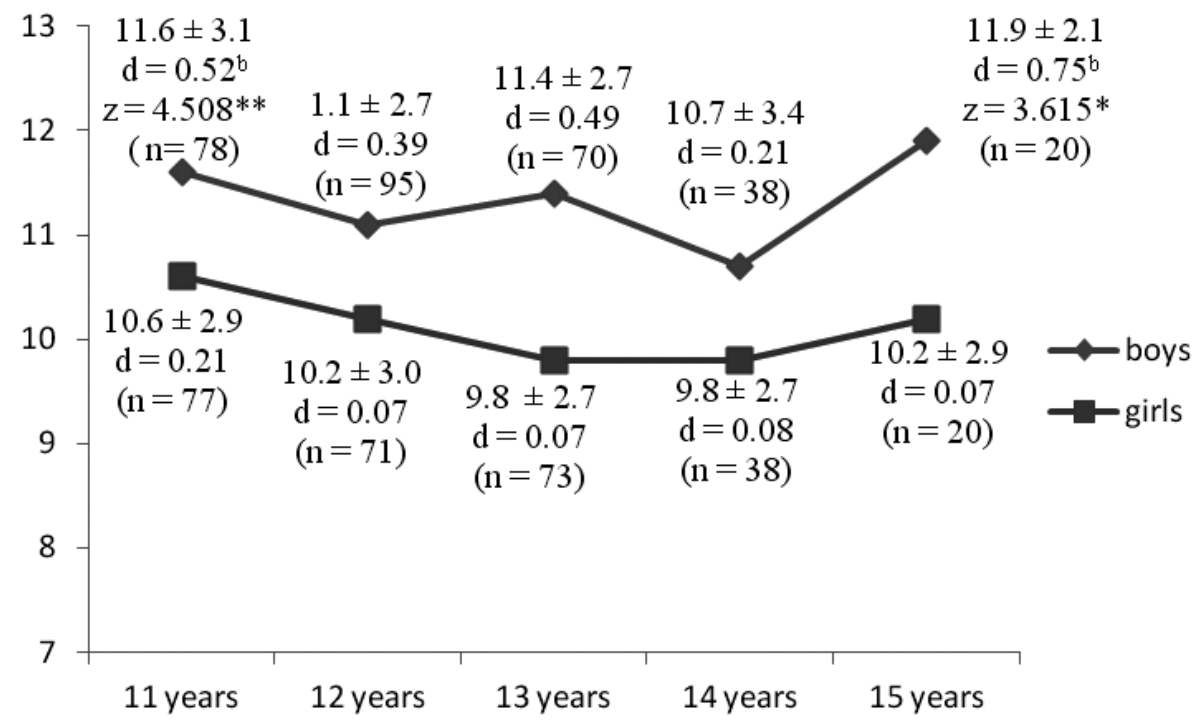

Legend: $\mathrm{d}$ - Cohen' effect size coefficient, ${ }^{\mathrm{b}}-$ a medium effect size, $\mathrm{z}-\mathrm{z}$-value in the z-test, ${ }^{*}-\mathrm{p}<.05,{ }^{* *}-\mathrm{p}<.001$ 
TABLE 3

Performance in the balance tests of the MABC-2 in the Czech children $(n=589)$; the significance of differences as compared to the mean performance of the United Kingdom standardisation sample $(n=344)$

\begin{tabular}{|c|c|c|c|c|c|c|}
\hline \multirow{2}{*}{ TEST } & Standard & \multirow{2}{*}{ d } & z-value & \multirow{2}{*}{$\begin{array}{c}\text { Standard } \\
\text { score }(\mathrm{M} \pm \mathrm{SD})\end{array}$} & \multirow{2}{*}{ d } & \multirow{2}{*}{$\begin{array}{l}\text { z-value } \\
\text { (z-test) } \\
\end{array}$} \\
\hline & score $(\mathrm{M} \pm \mathrm{SD})$ & & (z-test) & & & \\
\hline & 11 year old boys $(n=78)$ & & & 11 year old girls $(n=77)$ & & \\
\hline Bal 1 & $10.7 \pm 3.0$ & 0.23 & & $11.4 \pm 2.6$ & $0.52^{\mathrm{b}}$ & $4.636 * *$ \\
\hline Bal 2 & $9.9 \pm 3.1$ & 0.03 & & $10.2 \pm 3.0$ & 0.07 & \\
\hline \multirow[t]{2}{*}{ Bal 3} & $10.4 \pm 1.7$ & 0.19 & & $10.9 \pm 1.6$ & 0.43 & \\
\hline & 12 year old boys $(n=95)$ & & & 12 year old girls $(n=71)$ & & \\
\hline Bal 1 & $11.0 \pm 3.0$ & 0.33 & & $11.5 \pm 2.6$ & $0.54^{\mathrm{b}}$ & $4.851 * *$ \\
\hline Bal 2 & $10.4 \pm 2.9$ & 0.14 & & $10.2 \pm 3.1$ & 0.07 & \\
\hline \multirow[t]{2}{*}{ Bal 3} & $10.6 \pm 1.6$ & 0.29 & & $10.9 \pm 1.5$ & 0.45 & \\
\hline & 13 year old boys $(n=70)$ & & & 13 year old girls $(n=73)$ & & \\
\hline Bal 1 & $11.0 \pm 3.0$ & 0.33 & & $11.4 \pm 2.0$ & $0.58^{\mathrm{b}}$ & $7.814 * *$ \\
\hline Bal 2 & $10.6 \pm 2.8$ & 0.21 & & $10.9 \pm 2.5$ & 0.33 & \\
\hline \multirow[t]{2}{*}{ Bal 3} & $10.6 \pm 1.5$ & 0.30 & & $10.8 \pm 0.9$ & $0.50^{\mathrm{b}}$ & $8.058 * *$ \\
\hline & 14 year old boys $(n=51)$ & & & 14 year old girls $(n=38)$ & & \\
\hline Bal 1 & $10.8 \pm 3.0$ & 0.27 & & $10.7 \pm 3.0$ & 0.23 & \\
\hline Bal 2 & $10.7 \pm 2.8$ & 0.24 & & $9.6 \pm 3.3$ & 0.13 & \\
\hline \multirow[t]{2}{*}{ Bal 3} & $10.9 \pm 0.7$ & $0.60^{\mathrm{b}}$ & $9.200 * *$ & $10.6 \pm 1.8$ & 0.25 & \\
\hline & 15 year old boys $(n=16)$ & & & 15 year old girls $(n=20)$ & & \\
\hline Bal 1 & $10.3 \pm 3.5$ & 0.09 & & $11.9 \pm 2.1$ & $0.70^{\mathrm{b}}$ & $3.922 * *$ \\
\hline Bal 2 & $10.2 \pm 3.4$ & 0.06 & & $11.8 \pm 0.9$ & $0.78^{\mathrm{b}}$ & $9.000 * *$ \\
\hline Bal 3 & $11.0 \pm 0.0$ & $0.67^{\mathrm{b}}$ & $\# * *$ & $11.0 \pm 0.0$ & $0.67^{\mathrm{b}}$ & $\# * *$ \\
\hline
\end{tabular}

Legend: M - mean, SD - standard deviation, d - Cohen's effect size coefficient, ${ }^{b}-$ a medium effect size, ${ }^{* *}-\mathrm{p}<.001, \# * *-p<.001$, the z-value was infinite due to SD=0 in the Czech sample, Bal 1 - Two-board balance test, Bal 2 - Walking toe-to-heel backwards test, Bal 3 - Zig-zag hopping test

Fig. 3

The component standard score for balance $(M \pm S D)$ in the Czech children $(n=589)$; the significance of differences as compared to the mean performance of the United Kingdom standardisation sample $(n=344)$

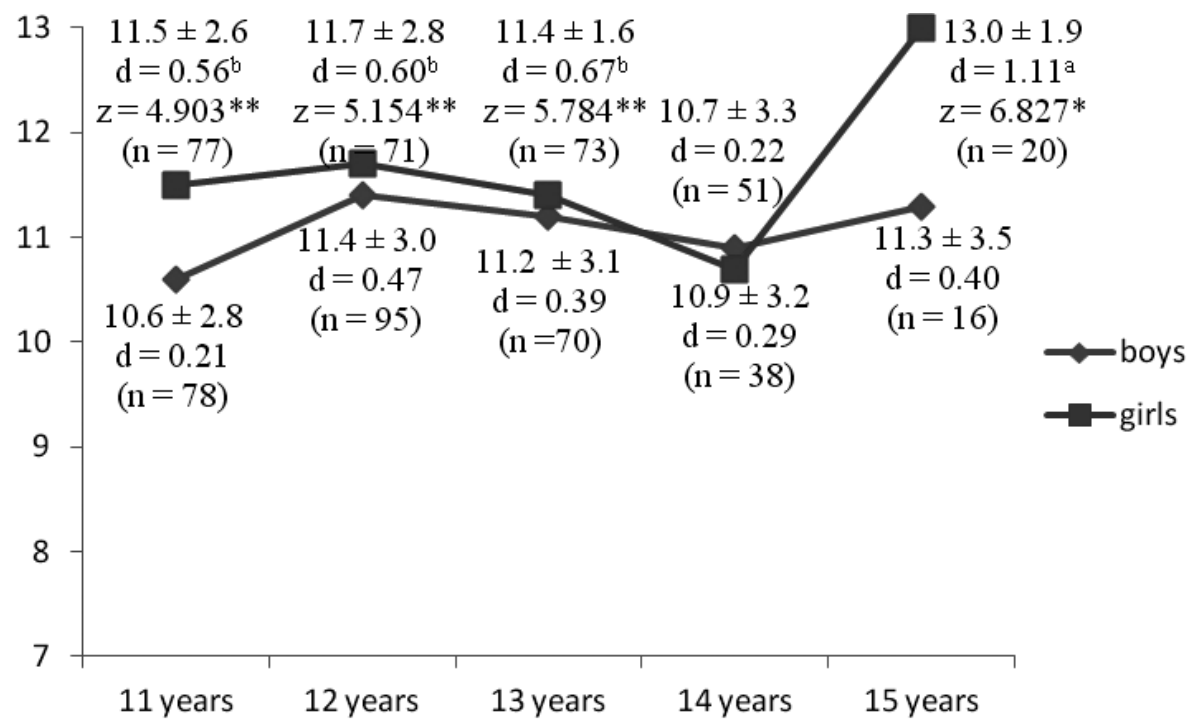

Legend: $\mathrm{d}$ - Cohen's effect size coefficient, a - a large effect size, $\mathrm{b}$ - a medium effect size, $\mathrm{z}-\mathrm{z}$-value in the z-test, ${ }^{*}-\mathrm{p}<.05,{ }^{* *}-\mathrm{p}<.001$ 
In contrast to the girls, the Czech boys showed from all the fifteen comparisons with the UK mean balance performance, a significantly higher performance only in the 14 and 15 year old subjects in the Bal 3 test (TABLE 3).

\section{DISCUSSION}

The construction of the MABC- 2 arose from the assumption of the construct of general motor ability of a human and its manifestation through fine and gross motor coordination, and balance. It has been supposed that these motor components are closely interwoven (Henderson et al., 2007). At the same time, each of these components is partly underlaid by the specific functional aspect (Burton \& Rodgerson, 2001). Thus, besides assessment of the general motor ability of a child, the MABC-2 enables evaluation of the possible functional difficulty of the given motor component.

Regarding assessment of fine motor coordination (manual dexterity), the unequivocal significant tendency of higher performance in the Czech children in the Drawing trail test (MD 3) was found in comparison to performance of the UK normative sample. In contrast to this result, in almost all age groups of Czech children performance in the Turning pegs test (MD 1) and Triangle with nuts and bolts test (MD 2) was below the UK mean presented by the standard score of 10 . It could be somewhat suprising as turning pegs, just as drawing trail, presents a task of unimanual coordination associated with the eye-hand system of a subject. However, functional specificity may be that turning pegs requires motor accuracy in hand dexterity, while drawing trail requires motor speed in hand dexterity. Ellinoudis, Kourtessis, Kiparissis, Kampas, and Mavromatis (2008) found a different factor loading of performance between these two tests in 10 and 11 year old children using the MABC. Hypothetically, significant differences in drawing trail performance in the Czech and UK samples could be partly influenced by the possible different experiences of the children from learning and practice of writing in the different school education systems. Otherwise, it is very difficult to interpret the difference of performance in the MD 3 test.

Markedly smaller standard deviations (SD) of standard score in the MD 3 test were found in the particular age groups of Czech children (TABLE 1) in comparison to $\mathrm{SD}=3$ in the UK normative sample showing lower inter-subject variability of performance in the drawing trail among Czech children. This finding suggested that the MD 3 test has a weaker differentiation property among the Czech children, associated with the ceiling effect.

Although significantly higher performance in the MD 3 test was observed, the manual dexterity com- ponent score, contributed from performance in three manual dexterity tests, was not significantly different when comparing the Czech sample to the UK mean. The good cross-cultural validity of the manual dexterity assessment with the MABC-2 was contributed by nonsignificantly lower performance in the MD 1 and MD 2 test as compared to the UK mean performance (with only one exception of the 11 year old Czech girls).

The assessment of gross motor coordination with the MABC-2 seemed to be valid for the Czech children when no significant differences of performance in the aiming and catching tests (AC 1 and $\mathrm{AC} 2$ ) were found between the Czech sample and UK normative sample. In addition, the distribution of individual performance in the Czech sample in these tests expressed by SD ranged in almost all age and gender groups from 2.5 to 3.5 of standard score (TABLE 2), and thus copied a normative distribution which is expressed by $\mathrm{SD}=3$. This finding supports the cross-cultural validity of gross motor coordination assessment by the MABC-2.

Only the 11 and 15 year old Czech boys achieved a significantly higher component score for gross motor coordination due to above average performance in both aiming and catching tests. The tendency of higher performance in aiming and catching skill in the Czech boys than girls was apparent, especially for 15 year old subjects (Fig. 2). This gender difference was also observed in the one-hand catching test and throwing at wall target test of the MABC in 11-12 year old Japan and USA children (Miyahara, Tsujii, Hanai, Jongmans, Barnett, Henderson, et al., 1998).

In contrast to the Czech boys, the balance performance of the Czech girls was significantly higher than the UK mean performance as indicated by the component score for balance (with the exception of 14 year old girls). This finding was mainly attributied to the significantly higher performance in the Two-board balance test (Bal 1). The Bal 1 test presents a static balance task in contrast to the the Walking toe-to-heel backwards test (Bal 2) and Zig-Zag hopping test (Bal 3) which are the dynamic balance tasks. Better postural stability of girls than boys of the same age mentioned in the literature (Lee \& Lin, 2007; Nolan, Grigorenko, $\&$ Thorstensson, 2005, and others) is rather related to static balance. Also this study suggested larger gender differences in static balance than in dynamic balance. Dynamic balance in boys can probably be improved during their development by participation in various movement and sport games that are typical movement activities for Czech boys (Kokštejn, 2011; Frömel, Novosad, \& Svozil, 1999).

The total test score (TTS) calculated from performance achieved in all eight tests of the MABC-2 is used as the criterion for identification of normal and impaired motor coordination of a child. TTS $\leq 5^{\text {th }}$ per- 
centile denotes having a significant movement difficulty and serves as criterion A for positive diagnosis of developmental coordination disorder (DCD) in a child according to the DSM IV-TR (American Psychiatric Association, 2000; Henderson et al., 2007). Further, TTS between the $6^{\text {th }}$ and $15^{\text {th }}$ percentile suggests the child's risk of having a movement difficulty.

$1.9 \%$ of boys and $0.7 \%$ of girls achieved TTS $\leq 5^{\text {th }}$ percentile, and $1.6 \%$ boys and $2.2 \%$ girls had TTS between the $6^{\text {th }}$ and $15^{\text {th }}$ percentile, respectively. This discrepancy in the percentage of Czech children in comparison to a normative distribution of total motor performance established as indicating mild and significant motor difficulties, respectively, can be partly explained by the following fact. The Czech primary schools participating in the study also include children with a mild or medium degree of specific learning disorders including DCD in the frame of the current strategy of inclusive education in the Czech Republic. However, children with more severe specific learning disabilities, and cognitive and sensory impairments are usually classified for special schools. However, the proportion of Czech boys and girls who were identified as having significant movement difficulty in the study ( $1.9 \%$ vs. $0.7 \%)$, was in accordance with the reports about a two to three times higher incidence of developmental coordination disorder in boys in the European populations of children (Kadesjo \& Gillberg, 1999, Maeland, 1992).

Results of the study can be partly limited for Czech population of the 15 year old children when a number of subjects of the Czech sample of this age was smaller. As compared to a general tendency, the performance in gross motor coordination and balance of the 15 year old boys and girls, respectively, could be considered abnormal (Fig. 2, 3).

\section{CONCLUSIONS}

This study revealed that the MABC-2 is valid only for assessment of gross motor coordination in 11-15 year old Czech children. Before use of this test battery in educational, psychological and clinical practice, and research in the population of Czech children, an adjustment of the norms is needed first of all for the Drawing trail test, Two-board balance test and Zig-zag hopping test. Moreover, a further cross-cultural verification of the MABC-2 should be carried out for 16 year old Czech children. This age category was not included in the study due to Czech primary schools not normally being attended by children of this age. In addition, a further examination of the MABC-2 should also include 15 year old children due to the smaller sample of children of this age in this study.

\section{ACKNOWLEDGEMENT}

The study was supported by the Czech Science Foundation in the frame of the projects No. P407/11/0946 and No. 406/09/1371.

\section{REFERENCES}

Brown, T., \& Lalor, A. (2009). The movement assessment battery for children - second edition (MABC-2): A review and critique. Physical \& Occupational Therapy in Pediatrics, 29(1), 86-103.

Burton, A. W., \& Rodgerson, R. W. (2001). New perspectives on the assessment of movement skills and motor abilities. Adapted Physical Activity Quarterly, $18,347-365$.

Cohen, J. (1977). Statistical power analysis for the behavioral science. New York: Academic Press.

American Psychiatric Association. (2000). DSM-IV-TR Diagnostic and statistical manual of mental disorder. Washington DC: APA.

Ellinoudis, T., Kourtessis, T., \& Kiparissis, M. (2008a). Suitability of the Movement Assessment Battery for Children in Greece: Comparison between a Greek sample and the North-American normative sample of 9 and 11 years old children. International Journal of Health Science, 1(4), 132-137.

Ellinoudis, T., Kourtessis, T., Kiparissis, M., Kampas, A., \& Mavromatis, G. (2008). Movement Assessment Battery for Children (MABC): Measuring the construct validity for Greece in a sample of elementary school aged children. International Journal of Health Science, 1(2), 56-60.

Frömel, K., Novosad, J., \& Svozil, Z. (1999). Pohybová aktivita a sportovní zájmy mládeže. Olomouc: Univerzita Palackého.

Henderson, S. E., \& Sugden, D. A. (1992). Movement Assessment Battery for Children. London: The Psychological Corporation.

Henderson, S. E., Sugden, D. A., \& Barnett, A. L. (2007). Movement Assessment Battery for Children 2. London: Harcourt Assessment.

Kadesjo, B., \& Gillberg, C. (1999). Developmental coordination disorder in Swedish 7 year old children. Journal of the American Academy of Child \& Adolescent Psychiatry, 38(7), 820-828.

Kokštejn, J. (2011). Pohybová aktivita dětí s motorickými obtižemi. Doctoral thesis, Charles University, Faculty of Physical Education and Sports, Prague.

Larkin, D., \& Rose, E. (2005). Assessment of developmental coordination disorder. In D. Sugden, \& M. Chambers (Eds.), Children with developmental coordination disorder (pp. 135-154). London, Philadephia: Whurr Publishers. 
Lee, A. J., \& Lin, W. H. (2007). The influence of gender and somatotype on single-leg upright standing postural stability in children. Journal of Biomechanics, 23(3), 173-179.

Maeland, A. F. (1992). Identification of children with motor coordination problems. Adapted Physical Activity Quarterly, 9(4), 330-342.

Miyahara, M., Tsujii, M., Hanai, T., Jongmans, M., Barnett, A., Henderson. S. E., Nakanisha, K., \& Kageyama, H. (1998). The Movement Assessment Battery for Children: A preliminary investigation of its usefulness in Japan. Human Movement Science, 17(4-5), 679-697.

Nolan, L., Grigorenko, A., \& Thorstensson, A. (2005). Balance control: Sex and age differences in 9 to 16 year olds. Developmental Medicine \& Child Neurology, 47(7), 449-454.

Rösblad, B., \& Gard, L. (1998). The assessment of children with developmental coordination disorder in Sweden: A preliminary investigation of the suitability of the Movement ABC. Human Movement Science, $17(4-5), 711-721$.

Ruiz, L. M., Graupera, J. L., Gutiérrez, M., \& Miyahara, M. (2003). The assessment of motor coordination in children with the Movement ABC test: A comparative study among Japan, USA and Spain. International Journal of Applied Sports Sciences, 15(1), 22-35.

Smits-Engelsman, B. C. M. (1998). Movement ABC: Nederlandse handleiding. Lisse: Swets en Zeitinger.

Wuang, Y. P., Su, J. H., \& Su, C. Y. (2012). Reliability and responsiveness of the Movement Assessment Battery for Children - second edition test in children with developmental coordination disorder. Developmental Medicine \& Child Neurology, 54(2), 160-165.

Yoon, D. Y., Scott, K., Hill, M. N., Levitt, N. S., \& Lambert, E. V. (2006). Review of three tests of motor proficiency in children. Perceptual and Motor Skills, 102(2), 543-551.

\section{TESTOVÁ BATERIE MABC - DRUHÉ VYDÁNÍ: MEZIKULTURNÍ SROVNÁNÍ 11-15LETÝCH DĚTÍ Z ČESKÉ REPUBLIKY A VELKÉ BRITÁNIE \\ (Souhrn anglického textu)}

VÝCHODISKA: S výjimkou speciálních klinických metod neexistuje v České republice standardně a široce užívaná diagnostická metoda pro hodnocení vývoje mo- toriky u dětí. Druhé vydání testové baterie Movement Assessment Battery for Children (MABC-2) se ukazuje jako jeden z nejrozvinutějších nástrojů hodnocení pohybové koordinace u dětí. Aby se tato testová baterie mohla platně použivat u populace českých dětí v psychologické a pedagogické praxi včetně tělesné výchovy, je potřeba tuto testovou baterii výzkumně ověrit na mezikulturní validitu.

CÍLE: Cílem studie bylo provést srovnávací analýzu výkonu v testových úlohách MABC-2 u souboru 11-15letých českých dětí a normativního souboru britských dětí.

METODIKA: U souboru 11-15letých českých dětí ( $\mathrm{n}=589, \mathrm{z}$ toho 310 chlapců a 279 dívek), který byl vytvořen náhodným výběrem škol ze všech zeměpisných regionů $\check{C} R$ a všech velikostních kategorií obcí, bylo provedeno hodnocení motoriky testy MABC-2. Výsledky byly srovnávány s testovými výkony u normativního souboru britských dětí stejného věku $(n=344)$, které uvádí manuál MABC-2 (Henderson et al., 2007). Pro srovnávací analýzu byl použit Cohenův koeficient velikosti účinku $d$ a z-test.

VÝSLEDKY: Z testů manuální dovednosti byl u souboru českých dětí zjištěn významně vyšší výkon v testové úloze Kreslení dráhy ve srovnání s výkonem britských dětí, a to ve všech věkových skupinách obou pohlaví $(\mathrm{d}=0.68-1.32 ; \mathrm{p}<0.01)$. Na druhou stranu výkony $\mathrm{v}$ testech hrubé motoriky se u souboru českých a britských dětí významně nelišily. $\mathrm{V}$ testu statické rovnováhy (Rovnováha na balanční desce) dosáhly téměř všechny věkové skupiny českých dívek významně vyšší výkon než britské dívky $(\mathrm{d}=0.52-0.70, \mathrm{p}<0.01) .14$ a 15letí čeští chlapci, ve srovnání s britskými chlapci, dosáhli vyšší výkon v testu Skákání po deskách se změnou směru. Významné motorické obtíže (celkové testové skóre $\leq 5$. percentil) byly zjištěny u $1.9 \%$ českých chlapců a $0.7 \%$ českých dívek.

ZÁVĚRY: Studie odhalila, že původní normy testové baterie MABC-2 jsou u populace českých dětí plně platné pouze pro hodnocení hrubé vizuomotorické koordinace, nikoli pro hodnocení manuální dovednosti a rovnováhy. Před použiváním této testové baterie jak pro praktické, tak výzkumné účely u populace českých dětí je nutné provést úpravu norem u testových úloh Kreslení dráhy, Rovnováha na balanční desce a Skákání po deskách se změnou směru.

Kličová slova: pohybová koordinace, test, manuální dovednost, mírení, chytání, rovnováha, dítě. 


\section{Doc. PaedDr. Rudolf Psotta, Ph.D.}

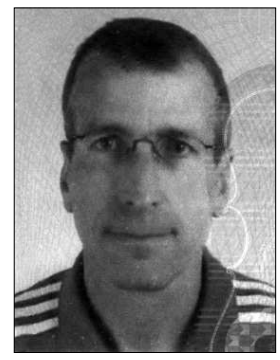

Palacký University, Olomouc

Faculty of Physical Culture

tř. Míru 115

77111 Olomouc

Czech Republic

\section{Education and previous work experience}

$\mathrm{He}$ has been affiliated with the Department of Natural Sciences in Kinanthropology at the Palacký University, Faculty of Physical Culture (Czech Republic) as an associate professor. He received his Ph.D. in the kinanthropology from the Charles University in Prague. His scientific interest is focused on the development and diagnostics of physical and motor performance in sports and other areas of human movement behavior. He is an author and coauthor of more than 140 publications, including several books.

\section{First-line publications}

Psotta, R., Bunc, V., Hendl, J., Tenney, D., \& Heller, J. (2011). Is repeated sprint ability of soccer players predictable from field based or laboratory physiological tests? Journal of Sports Medicine and Physical Fitness, 51, 18-25.

Psotta, R., Svěráková, D., Bunc, V., Šeflová, I., \& Hráský, P. (2009). Aerobic fitness, running performance and body composition of Czech elite male summer biathletes. International Journal of Fitness, 5, 41-49.

Psotta, R., Blahuš, P., Cochrane, D., \& Martin, A. J. (2005). The assessment of an intermittent high intensity running test. Journal of Sports Medicine and Physical Fitness, 45, 248-256.

Psotta, R., \& Bunc, V. (2004). An intermittent anaerobic running test: Reliability and factor validity in soccer players. Journal of Sport Sciences, 22, 557-558.

Psotta, R., Bunc, V., Tenney, D., Svěráková, D., Hráský, P., \& Šeflová, I. (2007). Physiological profile of Czech elite summer biathletes of both sexes. Gazetta Medica Italiana Archivio per le Science Mediche, 166, 169-180. 